DOI:10.17951/h.2020.54.1.7-17

\begin{tabular}{lcc}
\hline & A N N A L E S \\
UNIVERSITATIS MARIAE CURIE-SKŁODOWSKA \\
LUBLIN - POLONIA \\
SOL. LIV, 1 & SECTIO H \\
\hline
\end{tabular}

\author{
MARTA BARANIAK \\ marta.baraniak@uni.lodz.pl \\ University of Lodz. Faculty of Management \\ 22/26 Jan Matejko St., 90-237 Lodz \\ ORCID ID: https://orcid.org/0000-0002-6186-9514 \\ DOROTA STARZYŃSKA \\ dorota.starzynska@uni.lodz.pl \\ University of Lodz. Faculty of Management \\ 22/26 Jan Matejko St., 90-237 Lodz \\ ORCID ID: https://orcid.org/0000-0001-5355-016X
}

\title{
The Innovativeness of Individual Farms in the Łódź Region
}

Keywords: individual farms; FADN; innovation activity

JEL: Q14

How to quote this paper: Baraniak, M., \& Starzyńska, D. (2020). The Innovativeness of Individual Farms in the Łódź Region. Annales Universitatis Mariae Curie-Skłodowska, sectio H-Oeconomia, Vol. 54, No. 1.

\begin{abstract}
The aim of this paper is to characterise the innovativeness of individual farms in the Łódź region. Based on a domestic and foreign literature study, the most frequently used variables connected with farms (namely, the type of agricultural activity, economic size and VAT settlement system) were selected. The analysis of selected variables that characterise the innovative activity of the researched entities was carried out using the basic measures of structural analysis and interdependence of phenomena. The analysis was based on the results of questionnaire interviews conducted among 150 individual farms from the Łódź region which keep accounting books under the Polish FADN.
\end{abstract}




\section{Introduction}

Innovation in agriculture is an extremely difficult issue to analyse, mainly due to the lack of data in this field of research since the institutions that collect information on innovation activity carry out such activity without the knowledge of the agricultural sector (including the Central Statistical Office). Farms are treated as special cases and are not obliged to register their activity or to keep accounting books. The Farm Accountancy Data Network (FADN) is the only institution that gathers sensitive data from farms. The disadvantage of this system is the lack of information on the level of innovation of agricultural entities. However, the FADN system does make it possible to conduct research among farms that provide their accounting data, which increases the scope for research.

There is little material in the Polish literature on the innovative activity of farms due to the aforementioned difficulties in accessing data. However, perhaps due to this paucity, we were inspired to conduct our own research, which was carried out based on conclusions formulated by the authors of published papers.

Among the basic factors determining the implementation of innovation on farms are the economic size and the type of farm (Läppe, Renwick, \& Thorne, 2015, pp. 1-8). Evidence shows that larger and crop-based ${ }^{1}$ farms implement innovations more often (Diederen, van Meijl, Wolters, \& Bijak, 2003, pp. 30-60; Górka \& Ruda, 2012, pp. 126-131; van der Meulen, van Asseldonk, \& Ge, 2016, pp. 172-174). The determinant for innovation among agricultural entities may also be the age of the farmer running the farm, due to the fact that older farmers often have a lower level of education, and therefore less knowledge about innovative opportunities (van der Meulen et al., 2016, pp. 172-174). For that reason, many authors draw attention to the need for education in agriculture and professional development, which could allow for the links between agriculture and research to be strengthened, with the resultant co-creation of knowledge for the needs of farmers (Läppe et al., 2015, pp. 6-8). The impact of age on the implementation of innovation on farms was found to influence the decisions of scientists in the field of research planning. Research has been conducted among young farmers under 40 years of age (Kałuża \& Ginter, 2014, pp. 89-98; Kiełbasa \& Puchała, 2015, pp. 107-111), although these studies were mostly limited to a superficial analysis of innovation, including sources of knowledge about innovation and the motives for any innovative activity. According to Nasalski (2017, pp. 212-217), farmers implement innovations to increase production and sales, reduce costs, increase the quality and productivity of work and improve competitiveness.

Following an analysis of Polish and foreign literature and having drawn conclusions based on it about the lack of data, a survey was designed to discover the levels

\footnotetext{
1 Farms with only crop production.
} 
of innovation in individual farms ${ }^{2}$ in the Łódź region. The survey uses variables commonly found in the literature (economic size, farm type, motives for undertaking innovation activity) as well as the author's own variables, i.e. the VAT settlement system and the importance of innovation. The authors realise that there are many more variables, which will be covered in subsequent studies.

According to the Oslo Manual (OECD/Eurostat, 2005, p. 46), innovation is defined as "a new or improved product or process (or combination thereof) that differs significantly from the unit's previous products or processes and that has been made available to potential users (product) or brought into use by the unit (process)". The article investigates the implementation of innovations at three levels: farm, region (voivodeship) and country.

\section{Research methods}

The survey was carried out during January and February 2018 among individual farms located in the Łódź Voivodeship. Only agricultural entities that provided their accounting data under the FADN system were selected for questionnaire interviews using the PAPI technique. Farms that were eligible for study were indicated by the IERiGŻ-PIB (Institute of Agricultural and Food Economics - National Research Institute). The survey covered only agricultural entities with an economic size ${ }^{3}$ of more than EUR 25,000 with crop, animal or mixed production types ${ }^{4}$ - a total of 460 farms. Smaller entities (with an economic size of EUR 25,000 or less) were rejected due to their social nature and low level of investment and debt. In total, four economic group sizes of farms were classified for the study: medium-small, medium-large, large and larger. After the interviews, 150 correctly completed questionnaires were received, covering over $32 \%$ of the surveyed population of those individual farms in the Łódź region that do their accounting under the FADN system.

The empirical data obtained through the research were subjected to statistical analysis using the PS Imago program (whose "engine" is IBM SPSS Statistics). The characteristics of the surveyed farms, as well as their innovation activity, were decided on by using structural indicators. The V-Cramer coefficient with the Chisquare test was used to investigate the relationship between individual variables.

2 According to the FADN, the definition of "individual farms" includes: 1) farms with an area of 1 ha and more of agricultural land, 2) farms with an area of less than 1 ha of agricultural land (including those without agricultural land) conducting agricultural production (crop and animal) on a significant (defined by appropriate thresholds) scale, including special department of agricultural production (FADN, 2017, p. 4).

3 According to the FADN, economic size is determined by means of the sum of Standard Outputs (SOs) for all the agricultural activities carried out in a holding, expressed in euros. The SO is calculated per hectare or per head of livestock, by using basic data for a reference period of 5 successive years.

4 For research purposes, the types of agricultural production identified by FADN (field crops, horticulture, vineyards, permanent crops, dairying, grazing livestock, granivores, mixed) were aggregated into three categories: crop, animal and mixed farming. 


\section{Results}

This section of the paper presents selected variables characterising the 150 researched farms operating in the Łódź Voivodeship. First, the basic structural features of agricultural holdings, such as economic size, type of production and the VAT settlement system were created. Next, selected variables characterising their innovative activities were presented.

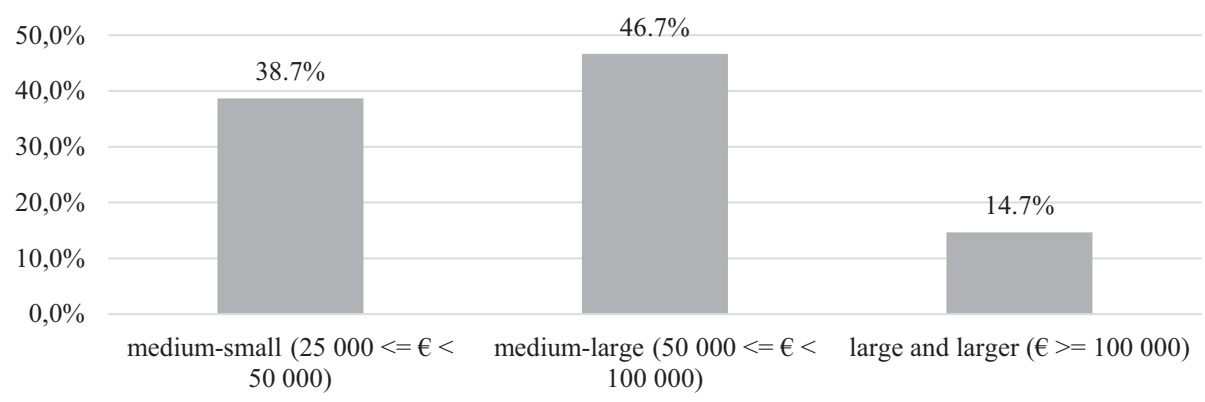

Figure 1. Structure of the researched individual farms by economic class size

Source: Authors' own study.

As mentioned previously, four economic class sizes of farms - medium-small, medium-large, large and very large - were selected for the research. Due to the small number of the largest economic size class of the surveyed entities, it was decided to combine the last two size classes into single class comprising of large and larger farms (see Figure 1). The most numerous groups among the researched units were medium-large farms, which made up nearly $47 \%$ of all the sample. A slightly smaller share $(38.7 \%)$ was recorded for medium-small farms, and less than $15 \%$ were farms belonging to the highest economic size class. The next analysed variable is the type of production of the researched entities (see Figure 2).

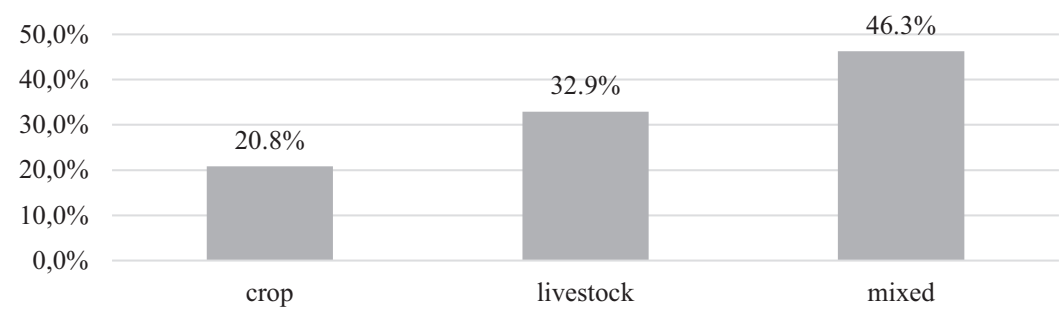

Figure 2. Structure of the researched individual farms by type of production

Source: Authors' own study.

Taking into account the type of production of the analysed entities, the most numerous groups were mixed farms - which made up slightly over $46 \%$ of all 
respondents. Nearly $33 \%$ were farms were involved in animal production, while $20.8 \%$ were crop farms.

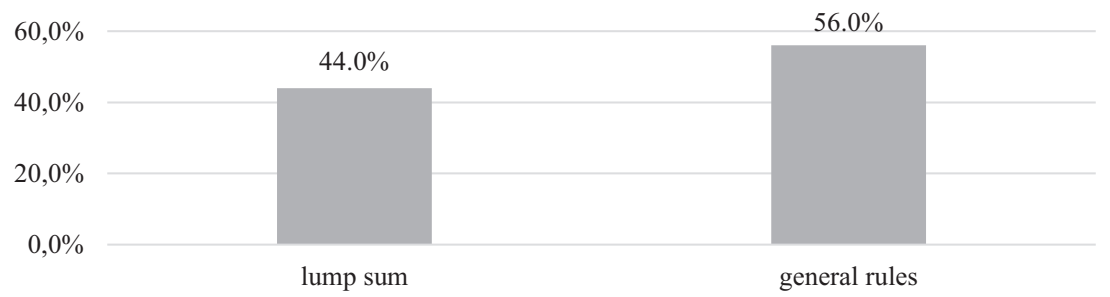

Figure 3. Structure of the researched individual farms by VAT settlement system

Source: Authors' own study.

The dominant form of VAT settlement in the group of analysed farms in the Łódź region are under general rules. This method was chosen by $56 \%$ of respondents, while the remaining group of farmers decided on a lump sum payment that does not require additional sales records, collections of invoices for the purchase of fuel, fertilisers or fixed assets. General rules were more often chosen by farmers whose type of production was focused on one activity, such as animal or crop production. In the case of mixedtype farms, general rules were less frequent than for other types of farming.

Later on, selected variables characterising the innovation activity of the researched individual farms will be presented, with particular regard to the specificity of production of particular entities. First of all, respondents were asked whether innovations are important for the development of farms (Figure 4). Over $84 \%$ of respondents confirmed that innovations are an important or very important factor as they allow for the growth and development of the surveyed entities. In contrast, $10.5 \%$ of respondents considered innovations as only slightly important, while more than $5 \%$ of respondents said that they were irrelevant to the development of their

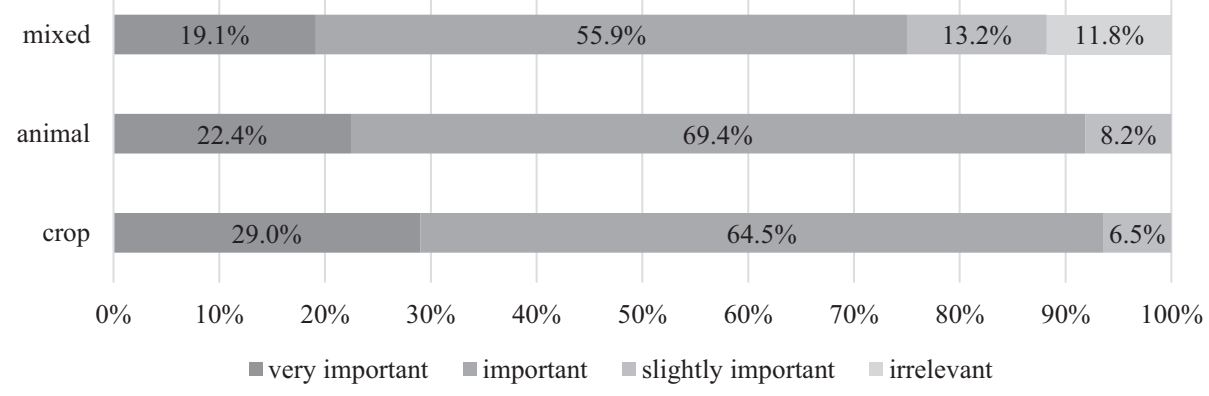

Figure 4. The importance of innovation and the type of production of the surveyed individual farms 
agricultural activity. A detailed analysis between the role of innovation in the development of individual farms in the Łódź region and the type of production confirmed that there is a statistically significant dependence $(V=0.21, p=0.05)$. Therefore, it can be claimed that innovations are more often useful to farms specialising in crop and animal production (see Figure 5).

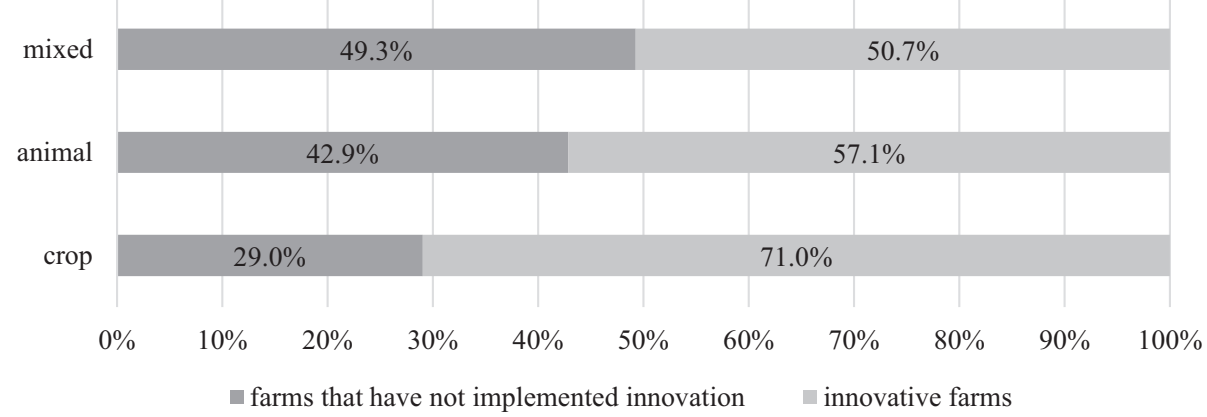

Figure 5. Structure of the surveyed individual farms by their innovativeness and the type of production

Source: Authors' own study.

In the group of surveyed entities, $57 \%$ of the farms declared that in the last three years they implemented at least one product or process innovation, while no such activities were reported among the other $43 \%$ of respondents. When considering the additional variable "type of production" in the analysis, it turned out that the majority of innovative farms could be found in the group of farms focused on crop production (71\%) and livestock $(57.1 \%)$. In the case of farms of mixed production, this percentage was less than $51 \%$ (see Figure 5).

The VAT settlement system used by the surveyed entities also impacts on innovation. The strength of the connection is relatively weak $(V=0.186)$, but nonetheless statistically significant $(p=0.023)$. Farms that have decided to settle VAT under general rules are characterised by higher levels of innovation than those using VAT exemption (see Figure 6).

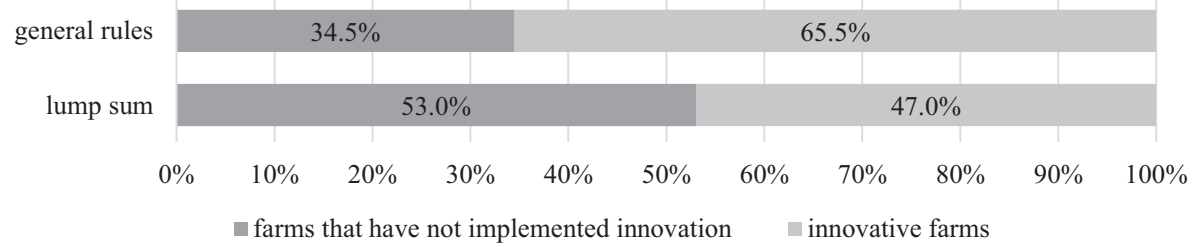

Figure 6. Structure of researched individual farms by their innovativeness and the VAT settlement system 
Between 2014 and 2016, more than $65 \%$ of farms settling VAT under general rules implemented at least one innovation. However, at the same time, only $47 \%$ of entities paying VAT in the form of a lump sum implemented new or improved products or services. Full settlement of VAT allows farmers the opportunity to receive a refund of the tax paid when purchasing new machinery and equipment necessary for implementing innovations. Thus, VAT can motivate farms' decisions regarding innovative activities.

Among the innovative farms, the most frequently implemented type of innovations were process innovations $(81.4 \%)$ followed by product innovations $(39.5 \%)$, while farmers made significant organisational or marketing changes much less often (see Figure 7).

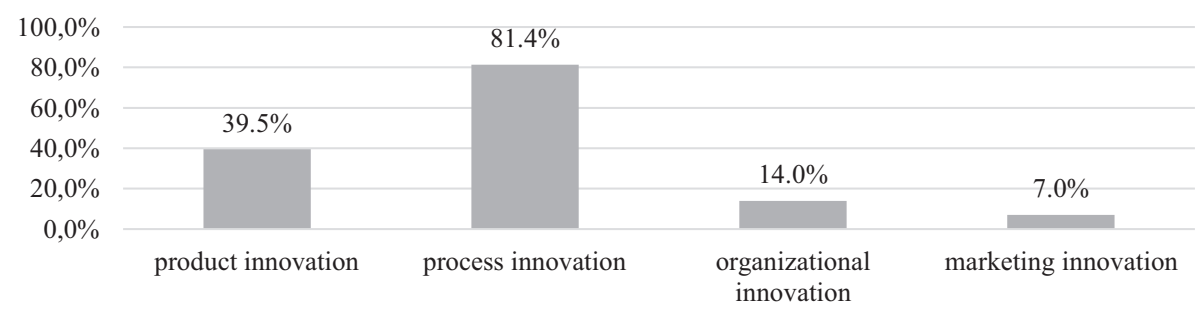

Figure 7. Type of implemented innovations among researched individual farms

Source: Authors' own study.

When considering the type of agricultural production, the results show that farmers who were focused on crop production were characterised by the highest levels of innovation activity, with almost $91 \%$ of this type of farm implementing process innovations and $45.5 \%$ adopting product innovations (see Figure 8). Only in $13.6 \%$ of cases were organisational innovations implemented, and marketing innovations were only implemented by $4.5 \%$ of the farms.

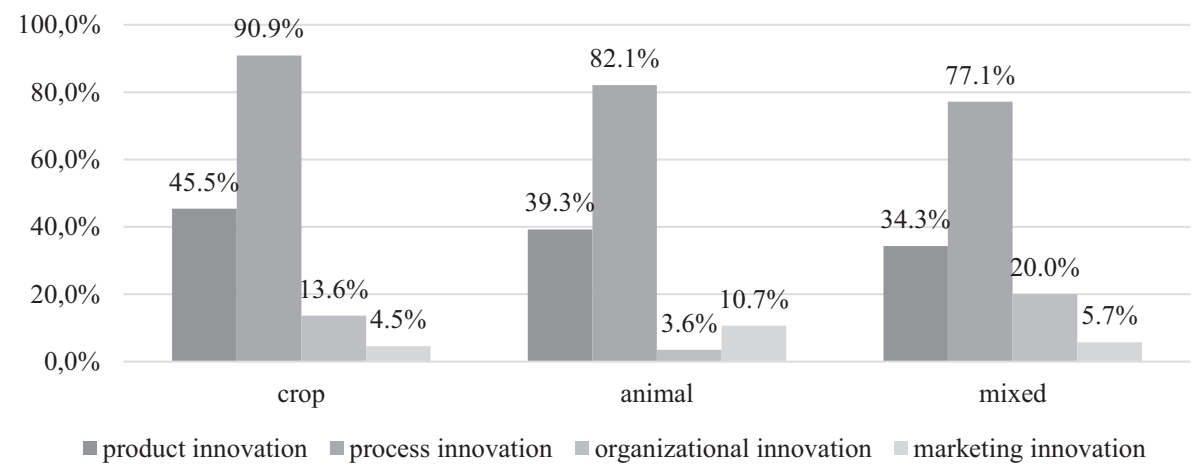

Figure 8. Type of innovations and the type of production of researched individual farms 
In farms with livestock production, the percentage of implemented innovations discussed was slightly lower, while weaker activity was recorded in the case of mixed farms.

The next analysed factor were the motives connected to the implemented innovation projects. Over $45 \%$ of farmers declared that they undertook innovation activity to increase the competitiveness of their farm. This was followed by a cost motivation - as stated by nearly $32 \%$ of responses. Less than $12 \%$ indicated that their main motive was pressure from competing farms. Other motives, such as increasing income, increasing productivity or the demand for innovative products determined the implementation of innovation activity by the surveyed farms to a significantly lesser extent (see Figure 9).

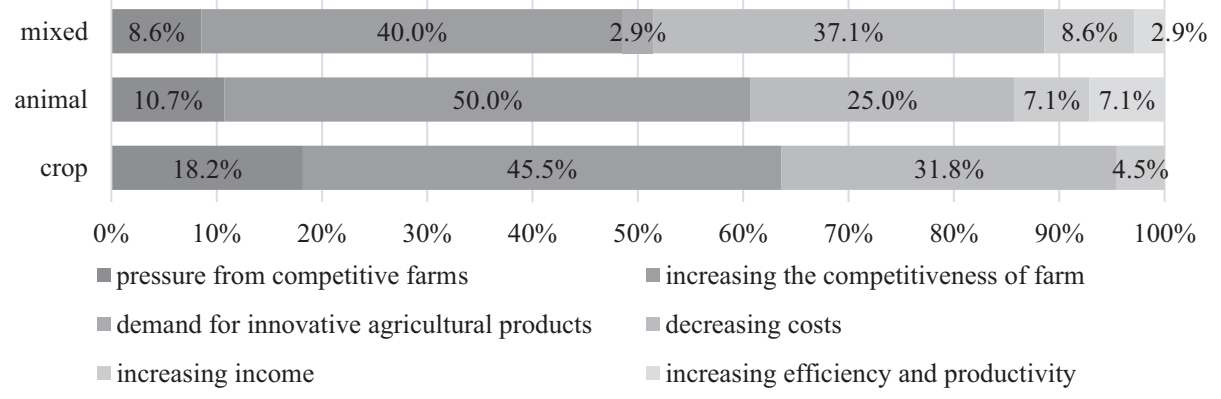

Figure 9. Motives for implementing innovations and the type of production of researched individual farms Source: Authors' own study.

Another aspect regarding the implemented innovation activity are the effects of previous implemented innovations. Respondents were asked whether innovation projects implemented in the last three years had met their expectations. In the case of $69 \%$ of respondents, the implemented innovations had met their expectations, while in $31 \%$ of cases, the effects were not entirely satisfactory.

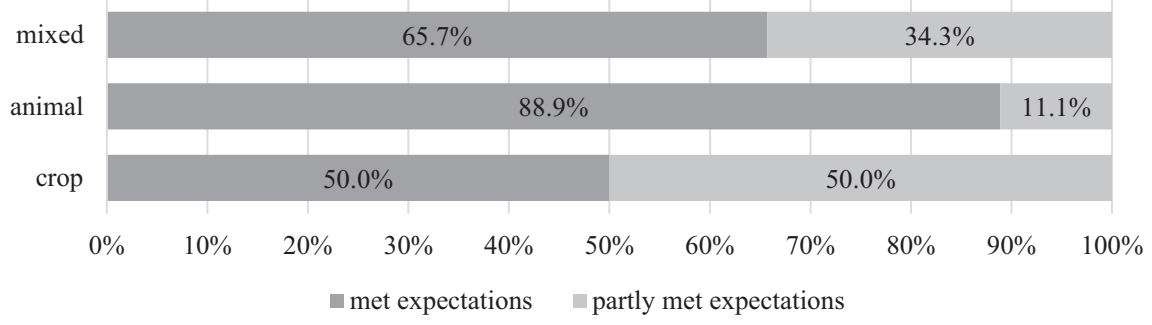

Figure 10. Effectiveness of implementing innovations and the type of production of researched individual farms 
The effectiveness of innovation activity varied depending on the type of agricultural production. Nearly $89 \%$ of farms characterised by animal production said that the implemented innovations met all their expectations, with only $11 \%$ of farms rating them as slightly worse. In the case of farmers specialising in crop production, only half of the surveyed farms stated that implemented innovations met their expectations, while the other $50 \%$ of respondents believed that the intended effects were only partially achieved (see Figure 10). Dependence analysis between the analysed variables confirmed that there was a statistically significant connection $(V=0.33$, $p=0.01)$.

In addition, respondents were asked about the main reason for failures related to the implementation of innovation. All were given a choice of five response options. Figure 11 presents this in a detailed structure. The results revealed that the declared reasons depended on the type of agricultural production. In the case of crop farms, only two factors were indicated: adverse weather conditions ( $72.7 \%$ of responses) and financial difficulties (27.3\% of responses).

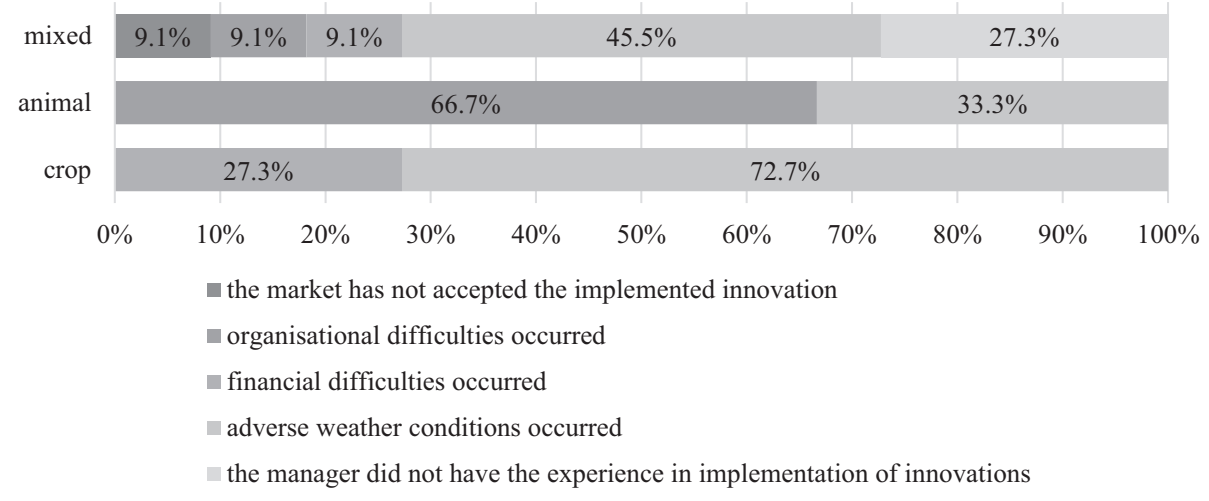

Figure 11. The main reasons for failures in implementing innovation activity and the type of production of researched individual farms

Source: Authors' own study.

A total of $66.7 \%$ of farmers managing farms with animal production indicated organisational difficulties, while $33.3 \%$ indicated financial difficulties. In the case of mixed farms, the main reason for the failures of implemented innovations were financial aspects $(45.5 \%)$, a lack of experience $(27.3 \%)$ and other factors $(9.1 \%)$. Moreover, analysis of the interdependence of phenomena confirmed that there is a strong and statistically significant connection $(V=0.58, p=0.03)$ between the type of agricultural activity and the reason for failures in the implementation of innovation. 


\section{Conclusions}

In light of the empirical research, it can be concluded that farmers appreciate the value of innovation with regard to achieving their development goals and keeping their competitiveness. Respondents almost unanimously believed that innovation is important for their particular agricultural activity, regardless of its type. However, the number of innovations actually implemented is more prevalent on crop farms, which confirms the conclusions formulated by some non-Polish studies (Diederen et al., 2003; van der Meulen et al., 2016). This is arguably due to the occurrence of a greater number of production problems when compared to other types of agricultural activity including natural disasters, pests, plant diseases or a fluctuation in the prices of agricultural products. It is, therefore, necessary to minimise any potential risks by implementing new technologies, production processes or new or improved varieties of vegetables and fruits that are resistant to disease or sudden changes in weather conditions.

Farms - in contrast to other entities of the national economy - implement process innovations far more often than product innovations, which is due to the characteristics of this type of business. In the agricultural sector, it is extremely difficult to implement product innovation to the market due to the lack of enthusiasm that consumers have for new food products. Therefore, farms focus instead on scale and increasing the quality of produced goods - in other words, process innovation.

The research was only carried out in the Łódź Voivodeship, and the FADN database used for this purpose makes it impossible to generalise the obtained results for the entire farming sector. To obtain a more complete picture of the innovativeness of agricultural entities, it would be necessary to conduct questionnaire interviews in other voivodeships. In this way, it would be possible to compare the innovativeness of agricultural entities within separate voivodeships and indicate its country-wide scale.

\section{References}

Diederen, P., van Meijl, H., Wolters, A., \& Bijak, K. (2003). Innovation adoption in agriculture: innovators, early adopters and laggards. Cahiers d'Économie et Sociologie Rurales, 67.

FADN. (2017). Opis realizacji planu wyboru próby gospodarstw rolnych dla Polskiego FADN w 2017 roku. Warszawa.

Górka, M., \& Ruda, M. (2012). Innowacje w gospodarstwach rolniczych województwa podkarpackiego. Nierówności Społeczne a Wzrost Gospodarczy, 29.

Kałuża, H., \& Ginter, A. (2014). Innowacje w gospodarstwach rolniczych młodych rolników. Prace Naukowe Uniwersytetu Ekonomicznego we Wrocławiu. Agrobiznes 2014. Rozwój agrobiznesu w okresie 10 lat przynależności Polski do Unii Europejskiej, 361. doi:10.15611/pn.2014.361.09

Kiełbasa, B., \& Puchała, J. (2015). Innowacyjność młodych rolników i ich postawy wobec zmian na przykładzie gospodarstw rolnych położonych w regionie rozdrobnionego rolnictwa. Roczniki Naukowe SERIA, XVII(1). 
Pobrane z czasopisma Annales $\mathrm{H}$ - Oeconomia http://oeconomia.annales.umcs.pl Data: 26/04/2023 16:07:02

Läppe, D., Renwick, A., \& Thorne, F. (2015). Measuring and understanding the drivers of agricultural innovation: Evidence from Ireland. Food Policy, 51. doi:10.1016/j.foodpol.2014.11.003

Nasalski, Z. (2017). Motywy podejmowania działalności innowacyjnej w gospodarstwach użytkujących grunty z zasobu własności rolnej Skarbu Państwa w województwie warmińsko-mazurskim. Roczniki Naukowe SERiA, XIX(3). doi:10.5604/01.3001.0010.3251

OECD/Eurostat. (2005). Oslo Manual. Guidelines for Collecting and Interpreting Technological Innovation Data. Paris.

Van der Meulen, H., van Asseldonk, M., \& Ge, L. (2016). The state of innovation in European agriculture: Innovators are few and far between. Studies in Agricultural Economics, 118. doi:10.7896/j.1628 